\title{
Effect of irrigation with different levels of saline water type on husk tomato productivity
}

\begin{abstract}
This investigation was carried out in a private farm located at Shebeen El-Qanatir city, El-Qaliubiya governorate, Egypt during the two successive seasons (2011/2012 and 2012/2013 A.D.) to study the response of husk tomato plants (Physalispubescens L.) cv. (local variety) to different levels of saline water. To test the growth ability of salt tolerance with best fruit yield and their quality under saline condition. Plants was irrigated with salty water with concentration of $2000,4000,6000$ and $8000 \mathrm{ppm}$. The control pot was irrigated with tap water at the level of $260 \mathrm{ppm}$. The results found that all water saline treatments significantly decreased the vegetative growth parameters \& total chlorophyll content, NPK in husk tomato leaves, early and total yield. On the contrary, irrigation with saline water significantly increased sodium and proline contents in husk tomato leaves, fruit firmness, total soluble solids and total sugars as compared with the control. The fruit yield productivity was decreased, while the fruit quality was increased under saline irrigation.
\end{abstract}

Keywords: salinity, chlorophyll, yield, total sugars, NPK, Physalispubescens L
Volume 6 Issue 4 - 2017

\author{
Helaly AA, 'Goda Y,' Abd El-Rehim AS,' \\ Mohamed AA,' El-Zeiny $\mathrm{OAH}^{2}$ \\ 'Horticulture Department,Al-Azhar University, Egypt \\ ${ }^{2}$ Horticulture Research Institute, Agriculture Ministry -Giza, \\ Egypt
}

Correspondence: Helaly AA, Horticulture Department, Faculty of Agriculture, Al-Azhar University, Cairo, Egypt, Email alaahelaly@hotmail.com

Received: December 27, 2016 | Published: March 02, 2017

\section{Introduction}

Husk tomato (Physalispubescens L.) is one of the most important vegetable crops in Egypt. The husk tomato belongs to the nightshade family (Solanaceae). The genus Physalis, established by Linnaeus in 1753 , contains about 463 species but 100 species are well known and have more fanciful names such as husk tomato, golden berry, ground cherry, strawberry tomato, Cape gooseberry and pubescent ground cherry. ${ }^{1,2}$ Physalis has been known in Egypt since the sixteen centuries under the name of its varieties 'Harankish', 'Halawyat' and 'El-Set El-Mestihya'. Because the fruit is covered in papery husk; giving it its name Husk tomato plants produce small orange fruits similar in size and shape to a cherry tomato. It is a hig. ${ }^{3}$ hly nutrition fruit; low in fat and contains no cholesterol or sodium. Husk tomato fruits provide an excellent source of the vitamin A and C, minerals (phosphorus and iron), protein, carotene, sugars and organic acids because of this they are a good choice for making health. ${ }^{2-4}$ Husk tomato (El-Set El-Mestihya, Harankish and Halawyat as Egyption people call) has been known in Egypt since long time ago by ancient of Egypt. Physalis is a very promising fruit. Recently, the economic importance of Physalis has risen, due to its high acceptance for local consumption, achieving great success in the African, Latin American and European markets. ${ }^{2,5,6}$ Many medicinal properties have been attributed to Physalis highly prized by Arab physicians as a medical plant for treating kidney diseases (as it purportedly disintegrated kidney stones) and urinary passage diseases. Recently, many studies have described the therapeutic applications and the pharmacological activity of the Physalis species as anti-parasitic, anti-viral, antineoplasic, antioxidant and anti-leukemic. ${ }^{5-7}$ Major problems still facing cultivation in new reclaimed lands, are salinity, drought and imbalanced nutrient elements. ${ }^{8}$ Salinity is one of the most important environmental constraints affecting more than 800 million hectares of arable land ${ }^{9-11}$ reported that the total salinity land is 953 ha which sharing $8 \%$ of the world area. The detrimental effects of high salinity on plants can be observed at the whole-plant level as the death of plants and/or decreases in productivity ${ }^{12}$ Salinity limits crops production, especially the sensitive ones. ${ }^{13}$ It affects morphological, physiological and biochemical processes, including seed germination plant growth and water and nutrient uptake. ${ }^{14}$ Percentage of dry weight, total soluble solids, and titratable acidity; content of reducing sugars, $\mathrm{Cl}, \mathrm{Na}^{+}$, and various pericarp pigments; and electrical conductivity of the juice were higher in tomato fruits of saline-treated plants than they were in those of control plants, while the $\mathrm{pH}$ was lower. ${ }^{15}$ Salt stress affects some major processes such as germination, speed of germination, root/shoot dry weight and $\mathrm{Na}^{+} / \mathrm{K}^{+}$ratio in root and shoot. ${ }^{16,17}$

Environmental stresses such as low temperature, salinity and drought limit crop productivity worldwide. ${ }^{18}$ Exposure to saline conditions is a detriment faced by many plants regardless of distance from large saltwater sources. According to the USDA nearly $30 \%$ of irrigated lands are of limited use because of salt intrusion, natural weathering or natural rainfall-based accumulation. Irrigation of plants or agricultural crops is the main cause of salt buildup in arid regions and areas where drainage in inadequate to remove excess salt. ${ }^{19,20}$ The saline area is three time larger than land used for agriculture. Total area under salinity is about 953 million ha covering about $8 \%$ on the land surface. Excess salt in soil solution may adversely affect plant growth either through osmotic inhibition of water uptake by roots or through specific ion effect. ${ }^{21}$ The objectives of this study were to analyses the effect of saline water irrigation controlled on growth, yield and fruit quality of husk tomato plant.

\section{Materials and methods}

The present study was carried out during the two successive seasons of 2011/2012 (first season) and 2012/2013 (second season) on husk tomato plant (PhyssalispubescensL.) cv. local variety (Figure 1). Plants were grown in a private farm located at Shebeen El-Qanatir city, El-Qaliubiya governorate, Egypt. A pot experiment was conducted to investigate the effect of irrigation with various levels of saline water on husk tomato plants. The used water was brought from Karun Lake at El-Fayoum Governorate. The saline concentration of this water was about $30560 \mathrm{ppm}$ salts which diluted with tap water to the required 
concentrations of 2000, 4000, 6000 and $8000 \mathrm{ppm}$. The control pot was irrigated with tap water at the level of $260 \mathrm{ppm}$. Chemical analysis of diluted drainage water is shown in Table 1 whereas physical and chemical properties of the soil which added to the pots are exhibited in Table 2. Pots were arranged in complete randomized design in three replicates. Each replicate consisted of seven pots. Seedlings were transplanted in pots as one transplant per pot (The pot contained wholes to drench the raised water, and its size was $50 \mathrm{~cm}$ in diameter and $80 \mathrm{~cm}$ in depth) filled with washed sand (30kg dried sand $/$ pot) and the experiment included 105 pots resulting from combination of 5 treatments within 3 replicate and every replicate consisted of 7 pots. Pots were irrigated with saline drainage water started after 10days from transplanting date. Plants were irrigated with saline water twice per a week and each pot received 3 liters of water to maintain soil continuously moistened in the pot. ECds $/ \mathrm{cm}$ of the pots drained water was measured after every irrigation treatment, then the saline concentration of irrigation water was adjusted again compared with the main level of saline water before the next irrigation treatment. Each pot was fertilized with ammonium sulphate $(10 \mathrm{~g})$, super phosphate $(8 \mathrm{~g})$ and potassium sulphate $(2.25 \mathrm{~g})$. The amounts of fertilizers were divided into two equal parts; the first was employed after 4 weeks from transplanting date whereas the second one was added after 8 weeks later.

Table I Chemical analysis of Karun Lake saline water after dilution with tap water

\begin{tabular}{|c|c|c|c|c|c|c|c|c|c|c|}
\hline \multirow[t]{2}{*}{ Salinity Levels } & \multirow[t]{2}{*}{ PH } & \multirow[t]{2}{*}{$\mathrm{EC} \mathrm{ds/m}$} & \multicolumn{4}{|c|}{ Cations (meq/L) } & \multicolumn{4}{|c|}{ Anions (meq/L) } \\
\hline & & & $\mathrm{Ca}^{++}$ & $\mathbf{M g}^{++}$ & $\mathrm{Na}^{+}$ & $\mathbf{K}^{+}$ & $\mathrm{HCo}_{3}^{-}$ & $\mathrm{HCO}_{3}$ & $\mathrm{Cl}-$ & $\mathrm{SO}_{4}^{-}$ \\
\hline Control at 260ppm & 7.9 & $0.4 \mathrm{I}$ & 1.5 & 1 & 2 & 0.15 & - & 3 & 1.5 & 0.15 \\
\hline $\mathrm{NaCl}$ at 2000ppm & 8.88 & 3.13 & 3.25 & 6.75 & 25.3 & 0.4 & - & 2.4 & 18.5 & 14.8 \\
\hline $\mathrm{NaCl}$ at $4000 p p m$ & 8.91 & 5 & 5 & 9 & 39.8 & 0.59 & - & 3.6 & 32 & 18.79 \\
\hline $\mathrm{NaCl}$ at $6000 \mathrm{ppm}$ & 8.98 & 7.5 & 6 & 17 & 57.6 & 0.97 & - & 5.4 & 51.5 & 24.67 \\
\hline $\mathrm{NaCl}$ at 8000 ppm & 8.9 & 10 & 8.5 & 21 & 79.3 & 1.3 & - & 7.5 & 74 & 24.6 \\
\hline
\end{tabular}

Table 2 Physical and chemical analysis of the pots soil before salinity experiments during20II/20I2 and 20I2/20I3 seasons

\begin{tabular}{|c|c|c|c|c|c|c|c|c|c|c|c|c|}
\hline \multirow[t]{3}{*}{ Seasons } & \multicolumn{4}{|c|}{$\begin{array}{l}\text { Physical } \\
\text { Properties }\end{array}$} & \multicolumn{8}{|c|}{ Chemical Properties } \\
\hline & \multirow[t]{2}{*}{ Sand\% } & \multirow[t]{2}{*}{ Silt\% } & \multirow[t]{2}{*}{ Clay\% } & \multirow[t]{2}{*}{ Texture } & \multirow[t]{2}{*}{$\begin{array}{l}\text { EC } \\
d s / m\end{array}$} & \multirow[t]{2}{*}{ PH } & \multicolumn{4}{|c|}{$\begin{array}{l}\text { Soluble cation } \\
\text { (meq/L) }\end{array}$} & \multicolumn{2}{|c|}{$\begin{array}{l}\text { Soluble anion } \\
\text { (meq/L) }\end{array}$} \\
\hline & & & & & & & $\mathrm{Na}^{+}$ & $\mathrm{Ca}^{++}$ & $\mathbf{M g}^{+}$ & $\mathbf{K}^{+}$ & $\mathrm{Hco}_{3}^{-}$ & $\mathrm{Cl}$ \\
\hline First season & 97.8 & 1.3 & 0.9 & Sand & 0.61 & 7.63 & 0.45 & 4.2 & 1.9 & 0.13 & 2.3 & I \\
\hline $\begin{array}{l}\text { Second } \\
\text { season }\end{array}$ & 97.2 & 1.5 & 1.3 & Sand & 0.31 & 7.95 & 0.38 & 4 & 1.7 & 0.15 & 2.1 & 1 \\
\hline
\end{tabular}

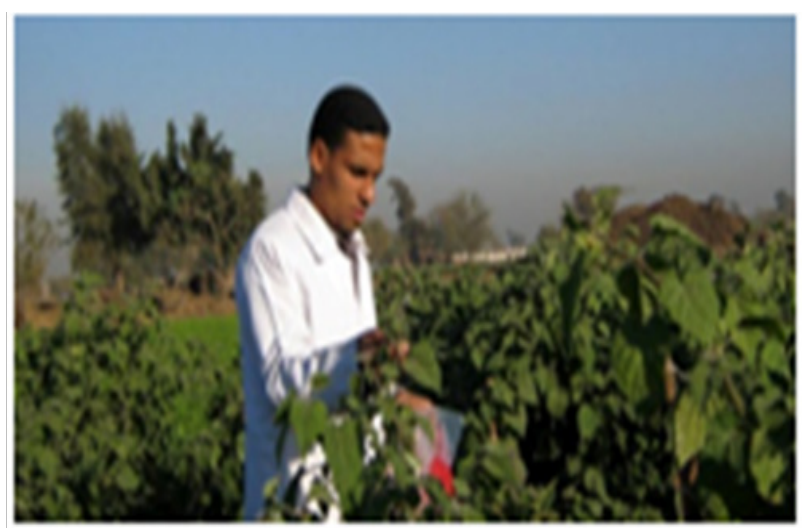

Figure I Physalispubescens L.) cv. local variety cultivated in Egypt.

\section{Data were recorded from each plot as following}

Vegetative characteristics :

Physical parameter: After five months from transplanting the following data were determined:

i. Plant height $(\mathrm{cm})$ was estimated from cotyledons level to the main shoot tip using miter trip. ii. Number of branches/plant was counted manually.

iii. Leaf area of the $5^{\text {th }}$ leaf from the shoot tip (measured by Li-300 leaf area meter produced by Li-Cor, Pinclivania).

iv. Stem diameter $(\mathrm{cm})$ was calculated by Vernier Caliper.

\section{Chemical parameters}

i. Leaves were dried in an oven at $70^{\circ} \mathrm{C}$ till constant weight to determine chemical constituents of (N, P, K, Na and Proline).

ii. Total chlorophyll content $(\mathrm{mg} / 100 \mathrm{~g}$. f. w.) was determined by the spectrophotometric method described by Helaly. ${ }^{22}$

iii. Nitrogen (\%) was determined by micro Keldjahel method according to A.O.A.C.

iv. Phosphor, potassium and sodium (\%) were determined by Flame photometer according to. ${ }^{23}$

v. Free proline content (mg /100 g. f. w.) was determined according to the method described by Cottenie et al. ${ }^{24}$

\section{Fruit characteristics}

\section{Yield parameters:}

i. Number of fruits per plant was counted during the whole period of 
harvesting in three plants as a sample.

ii. Early yield per plot $(\mathrm{Kg})$ : Was calculated as the total fresh weight of fruits harvested from the first fourth pickings.

iii. Total yield per plant $(\mathrm{kg})$ : Was calculated as weight of all harvested fruit per plant throughout the whole season.

iv. Total yield per plot $(\mathrm{Kg})$ : Was calculated as weight of all harvested fruit per plot throughout the whole season.

Physical parameters : A random sample of 20 fruits from each plot was randomly chosen to determination of:

i. Average fruit weight (g) was measured by a digital balance.

ii. Fruit size $(\mathrm{cm} 3)$ was measured by measuring the water volume displaced by immersing the fruits in graduated Jar filled with water.

iii. Fruit diameter $(\mathrm{cm})$ was estimated by Vernier Caliper.

iv. Fruit firmness $\left(\mathrm{kg} / \mathrm{cm}^{2}\right)$ was measured using a pressure tester (Digital Force-Gouge Model FGV-0.5A to FGV-100A. shimpo instruments).

\section{Chemical parameters:}

i. Total soluble solids (TSS \%) was determined by hand Refractometer according to A.O.A.C.

ii. Total titratable acidity ( $\mathrm{g}$ citric/100g fresh weight) was determined by titration with $0.01 \mathrm{~N} \mathrm{Na} \mathrm{OH}$ using phenolphthalein as indicator according to A.O.A.C.

iii. Vitamin C (Ascorbic acid) (mg/100g f.w.) was estimated by titration with 2,6-dichlorophenolindophenol dye according to A.O.A.C.

iv. Total sugars: Total sugars content in the curd were determined as (g/100g dryweight) according to. ${ }^{25}$

v. Total carotenoids (mg/100 g f.w.) were determined using spectrophotometer and calculated by using watt stein formula as described in $^{22}$

vi. Fruit dry matter (\%): Fruit samples were dried in an oven at $70^{\circ} \mathrm{C}$ till constant weight and the dry matter calculated according to the following formula: Dry matter $(\%)=$ Dry weight/Fresh weight * 100

\section{Statistical Analysis}

All experiments were statistically analyzed in a complete randomized design with three replicates. Each replicate consisted of six plants. Obtained data were subjected to the analysis of variance procedure and means were compared by L.S.D. method at $5 \%$ level of significant according to. ${ }^{26}$
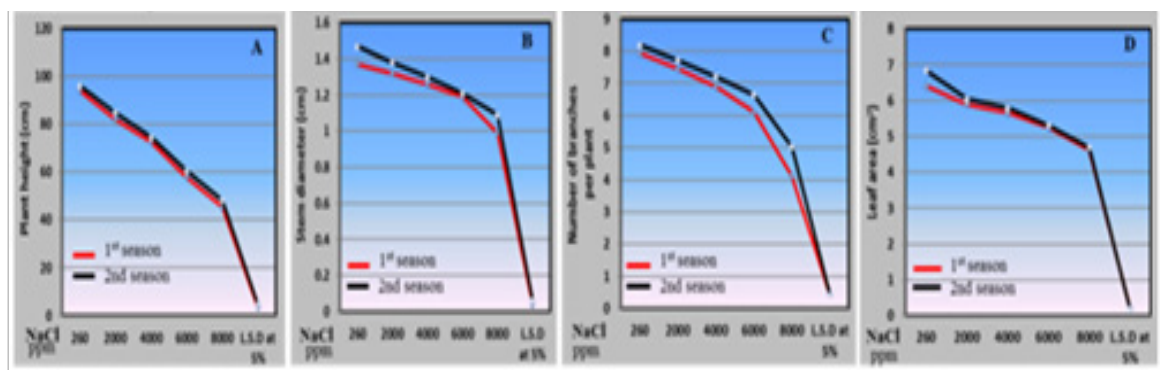

Figure 2 Effect of irrigation with saline water levels on plant height (A), stem diameter (B), number of branches per plant (C) and leaf area (D) of husk tomato plants during $2011 / 2012$ and $2012 / 2013$ seasons.

Citation: Helaly AA, Goda Y, El-Rehim ASA, et al. Effect of irrigation with different levels of saline water type on husk tomato productivity. Adv Plants Agric Res. 2017;6(4):I I4-I20. DOI: 10.15406/apar.2017.06.00223 
Chemical parameters: The present study of chemical parameters of husk tomato plants, which included total chlorophyll content in leaves, macro and micro elements $(\mathrm{N}, \mathrm{P}, \mathrm{K}$ and $\mathrm{Na}$ ) and proline under irrigation with saline water from 2000 to $8000 \mathrm{ppm}$, as shown in Figures 3 and Figure 4 reflected two different trends. The first trend pointed to positive increase in sodium and proline percentage by increasing saline water levels from 2000 to $8000 \mathrm{ppm}$. Regarding the increase in $\mathrm{Na}$ percentage in husk tomato leaves by increasing saline water irrigation levels from 2000 to $8000 \mathrm{ppm}$ may be attributed to the rise of $\mathrm{pH}$ level in the root zone resulted from salinity led to unavailability of potassium and calcium for the plant and also leads to accumulation of sodium inside the leaves ${ }^{8,36}$ and. ${ }^{35}$ On the other side the present results about increment of proline percentage in husk tomato leaves due to the irrigation with saline water is in agreement with the results obtained with $^{35}$ on tomato plants. However, many researchers demonstrated that plants accumulate proline in their leaves as a nontoxic and protective osmolyte under saline conditions. ${ }^{37}$ Proline accumulation under stress might occur due to an increase in pyrroline-5-carboxylate synthetase (P5CS), the rate-limiting enzyme in proline biosynthesis ${ }^{38}$ and a decrease of proline dehydrogenase (PDH) activity. ${ }^{39}$ The second trend showed a negative drop in total chlorophyll content, N, P and $\mathrm{K}$ in husk tomato leaves with every increase in saline levels. The negative effect of saline water irrigation on total chlorophyll content in husk tomato leaves in this study is attributed to salinity which indicates stress and damage to the photosynthetic apparatus. A decline in the level of photosynthetic pigments may be attributed to salinityinduced inhibition of chlorophyll biosynthesis. ${ }^{40}$ Salinity stress induced lower fresh weight and chlorophyll concentration of pumpkin genotypes. It has been reported that the typical symptom of salinity injury to the plant is the growth retardation due to the inhibition of cell elongation. ${ }^{41,42}$ Also, those harmful effects of salinity attributed to the inhibited effects on the activity of iron that reflect on reduction in rate of chloroplast structure and chlorophyll accumulation in tomato plant. ${ }^{43}$ From point of view salinity adversely affect the carbon fixation in photosynthesis, the lowest photosynthetic ability under salt stress conditions was due to stomata closure, inhibition of chlorophyll synthesis or due to decrease in the absorption of minerals needs for chlorophyll biosynthesis i.e. iron $^{43}$ on tomato. Our results are in agreement with those obtained with ${ }^{8-12}$ on tomato.
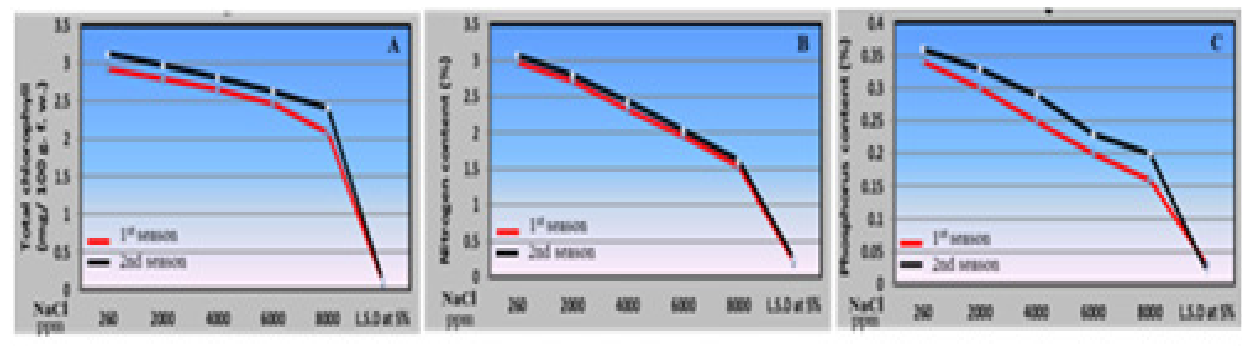

Figure 3 Effect of irrigation with saline water levels on total chlorophyll (A), nitrogen (B) and phosphorus (C) contents of husk tomato leaves during 201 I/20I2 and $2012 / 2013$ seasons.

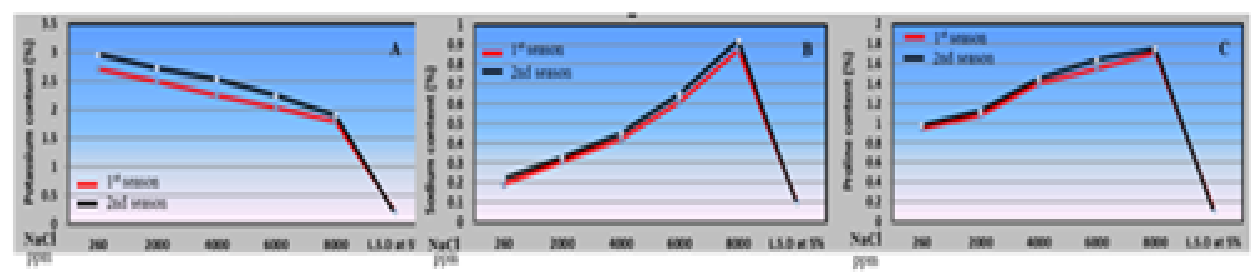

Figure 4 Effect of irrigation with saline water levels on potassium (A), sodium (B) and proline (C) contents of husk tomato leaves during 20II/20I2 and $2012 / 2013$ seasons.

The significant reduction in $\mathrm{N}, \mathrm{P}$ and $\mathrm{K}$ percentage were noticed at the levels from 2000 to $8000 \mathrm{ppm}$, water salinity and this reduction increased gradually with increasing salinity. The least percentage of the previous elements in leaf tissues of husk tomato plants was obtained by using saline water at $8000 \mathrm{ppm}$. The reason of the reduction effect of saline water on nitrogen content in husk tomato leaves is due to the interaction effect between chlorine and nitrate. Chlorine accumulation decreased nitrate content in tomato and eggplant ${ }^{44}$ Furthermore, the decreasein potassium content is due to an antagonistic effect between sodium and potassium. ${ }^{45}$

Moreover, the negative effect of water salinity on the percentage of $\mathrm{N}, \mathrm{P}$ and $\mathrm{K}$ in husk tomato leaves may be due to the differences between osmotic pressure inside and outside the plants, i.e. around the root zoon and plant tissues ${ }^{35}$ on tomato. Our result is in agreement with those obtained with ${ }^{34}$ on Cape gooseberry.

\section{Fruit characteristics}

Physical parameters: Data presented in Figure 5 obvious that the irrigation with saline water levels induced change in the physical parameters of husk tomato fruits. Saline water irrigation levels from 2000 to $8000 \mathrm{ppm}$ caused a reduction in some physical characteristics i.e. average fruit weight, size and fruit diameter, but it caused an increase in fruit firmness. The negative effect of saline water in average fruit weight, size and fruit diameter with very increase in saline water levels may be attributed to water uptake by husk tomato plants declines with the increase in salt concentration in irrigation water ${ }^{46}$ causing the decrease in fruit weight. ${ }^{47}$ Furthermore, reported that, tomato yield reduction was mostly associated with smaller fruit size. This was caused by a reduced enlargement rate during the exponential phase of fruit growth, which has been reported to be particularly sensitive to ionic and osmotic damages caused by ion accumulation in the plants throughout the growth season. Our results are in agreement with $^{8}$ on tomato. In regarding to increase husk tomato fruit firmness in our investigation by saline water irrigation is due to increased salinity effect originating from reduced fruit water content due to adaptation of the plant to salinity. Same results were detected with ${ }^{8,48}$ on tomato. 
Chemical parameters: Concerning the results of fruit Chemical characteristics which included total soluble solids (T.S.S.), total titratable acidity, vitamin C "ascorbic acid", total sugar, total carotenoids and dry matter under irrigation with saline water from
$2000,4000,6000$ and $8000 \mathrm{ppm}$ reveal to irrigated with tap water as presented in Figure 6, Figure 7 reflected that a positive increase in all previous characters were obtained except total carotenoids.
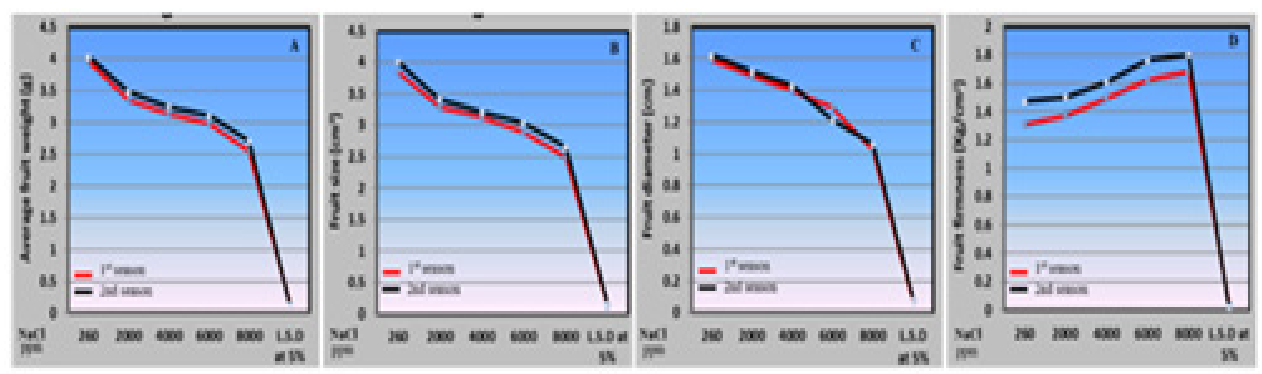

Figure 5 Effect of irrigation with saline water levels on average fruit weight (A), size (B), diameter (C) and firmness (D) of husk tomato fruits during 20I I/20I2 and $2012 / 2013$ seasons.

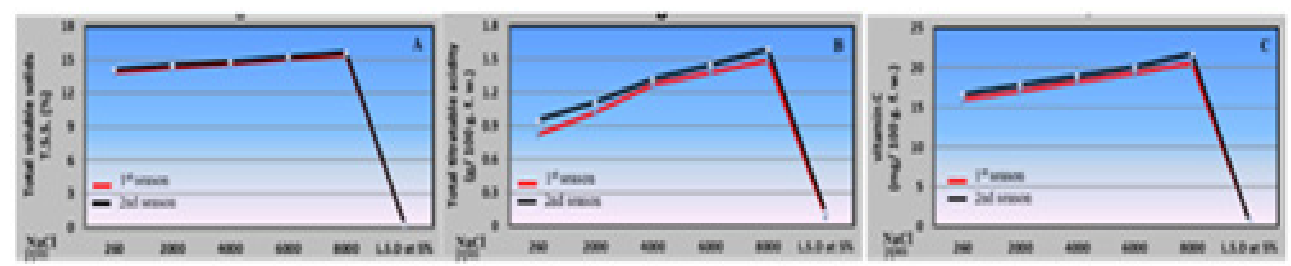

Figure 6 Effect of irrigation with saline water levels on total soluble solid (T.S.S.) (A), total titratable acidity (B) andVitamin C (ascorbic acid) (C) of husk tomato fruits during $2011 / 2012$ and $2012 / 2013$ seasons.
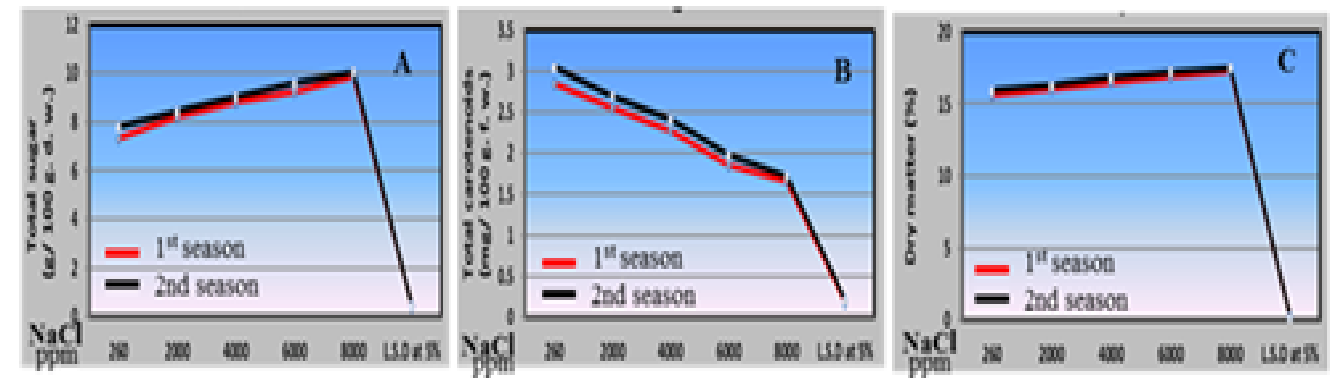

Figure 7 Effect of irrigation with saline water levels on total sugars (A), carotenoids (B) and dry matter (C) of husk tomato fruits during 20II/20I2 and $2012 / 2013$ seasons.

The enhancing contents of total soluble solids and ascorbic acid in husk tomato fruits by increasing saline water irrigation may be attributed to saline concentrations effect originating from reduced fruit water content due to adaptation of husk tomato plants to salinity. ${ }^{48} \mathrm{Also}$, in this study, husk tomato fruits grown under saline water irrigation show high titratable acidity, this may be attributed to the accumulation of organic acids in husk tomato fruits grown under salinity seems to counter balance the cation $\left(\mathrm{K}^{+}\right.$and $\left.\mathrm{Na}^{+}\right)$excess respective to anions $\left(\mathrm{Cl}^{-}\right.$and $\left.\mathrm{So}_{4}^{-}\right)$so maintaining fruits $\mathrm{pH}^{49}$ On the other hand, the enhancing total sugar in husk tomato fruits by increasing salinity levels may be attributed to activity of sucrose synthesis enzymes intensified when plants cultivated under high salinity as reported by Davies $^{50}$ on tomato plants. In addition, increased total soluble solids, acidity and sugar content associated with saline irrigation may also be ascribed to concentration effects due to smaller fruit size as reported by $\mathrm{Ho}^{51}$ Our results are agreement with ${ }^{8}$ on tomato.

\section{Yield parameters}

Regarding the yield characteristics (number of fruits per plant, early and total yield per plot), obtained from husk tomato plants grown under various concentrations of saline water, results in Figure 8 indicated that saline water irrigation from 2000 to $8000 \mathrm{ppm}$ caused a reduction in the previous characters.

The negative effect of the saline water attributed to the negative effect of saline water irrigation on leaf area, total chlorophyll content and NPK percentage in leaves which in turn built low yield of carbohydrate that consequently reduce the previous characters as mentioned $^{52,53}$ who reported that saline irrigation caused a reduced development of salinized plants, which consequently manifested a reduced transpiration rate; salt-induced inhibition of the root pressure, which in turn would result in a reduced water movement into the xylem, contributing to lower water uptake by roots; and decreased soil permeability. Many researchers reported that, salinity is a major abiotic factor limiting plant growth and fruit yield. ${ }^{12}$ It induces osmotic and toxic effects leading physiological, morphological and biochemical modifications; it causes growth inhibition, crop yield reduction, lower photosynthesis and respiration, nutritional deficiencies and inhibition of protein synthesis. ${ }^{33}$ Our results are in agreements with and ${ }^{8,54}$ on tomato. 


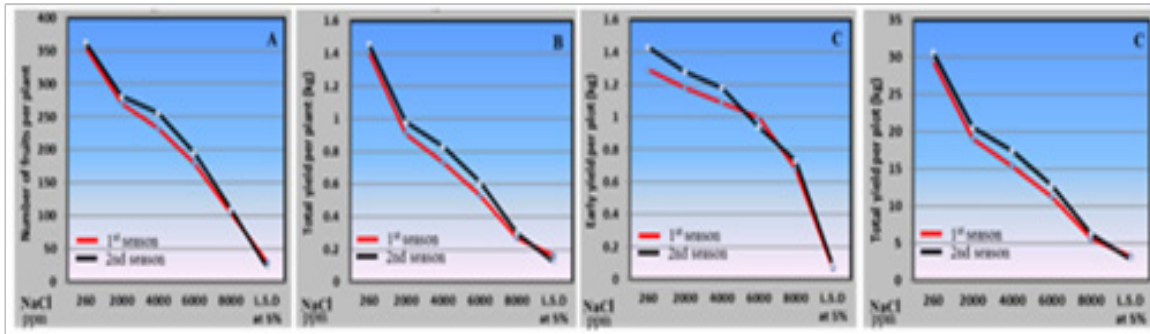

Figure 8 Effect of irrigation with saline water levels on number of fruits per plant (A), total yield per plant (B), early yield per plot (C) and total yield per plot (D) of husk tomato during $201 \mathrm{I} / 2012$ and $2012 / 2013$ seasons.

\section{Conclusions}

This experiment succeeded in providing evidence that husk tomato can grow well under $2000 \mathrm{ppm}$ of salinity with satisfying productivity and quality. ${ }^{55}$

\section{Acknowledgements}

Authors are grateful to Al-Azhar University, Faculty of Agriculture, Horticulture department, Government of Egypt for supporting this research project to carry out this work. The authors express their gratitude to, Prof. Dr. Abd El-Naem Said Abd El-Rehim and Prof. Dr. Mohamed Tarek Gaafar Al-Abd Professors of vegetable crops, Horticulture Department, Faculty of Agriculture, Al-Azhar Universityfor their Support, constructive suggestions, supervision, advice, sincere help and valuable guidance throughout the course of this study. ${ }^{56}$

\section{Conflict of interest}

The author declares no conflict of interest.

\section{References}

1. El Sheikha AF. Technological, chemical and microbiological studies on some packed foods. Master Sci, Egypt: Fac Agri Minufiya Univ; 2004. $174 \mathrm{p}$.

2. Goda Y, Abd El-Rehim AS, Mohamed AA, et al. Effect of shoot Pruning on Growth, Yield and Fruit Quality of Husk Tomato (Physalis pubescens L.). Journal of American Science. 2014;10(1):5-10.

3. Elskeikha AF, G Piombo T, Goli Montet. Main composition of physalis pubsciencs L. fruit juice from Egypt. Fruits. 2010;65(4):255-265.

4. Mustafa AMM. Effect of nitrogen, potassium fertilization and their interactions on yield and quality of husk tomato. MSc Thesis Fac Agric Alexandria University; 2009.

5. El Sheikha AF, Zaki MS, Bakr AA, et al. Physicochemical properties and biochemical composition of Physalis (Physalis pubescens L.) fruits. Food. 2008;2(2):124-130

6. El Sheikha AF, Zaki MS, Bakr AA, et al. Biochemical and sensory quality of Physalis (Physalis pubes-cens L.) juice. J Food Proc Preserv. 2010;34:541-555.

7. El Sheikha AF. Physalis fruits from paradise, In: Trace 5th Annu Meet Int Conf. Trace in practice (New methods and systems for confirming the origin of food) (Poster), Freising, Germany; 2009.

8. Tantawy, AESA. Effect of some mineral and organic compounds on salinity tolerance in tomato. Ph D Thesis, Fac Agric Al-Azhar Univ; 2007.

9. Munns R, Tester M. Mechanisms of salinity tolerance. Ann Rev Plant Biol. 2008;59:651-681.
10. Lokhande VH, Nikam TD, Penna S. Biochemical, physiological and growth changes in response to salinity in callus cultures of Sesuvium portulacastrum L. Plant Cell Tiss Org Cult. 2010;102:17-25.

11. Jan N, Gautam YK, Vimala Y. Higher salt tolerance of physalis peruviana L. callus with reduced peroxidase activity compared to its in vitro raised seedlings. Int J Res Ayurveda Pharm. 2015;6(2):272-276.

12. Parida AK, Das AB. Salt tolerance and salinity effects on plants, a review. Ecotoxicology and Environmental Safety. 2005;60(3):324-349.

13. Zadeh HM, Naeni MB. Effects of salinity stress on the morphology and yield of two cultivars of canola (Brassica napus L). J Agron. 2007;6:409-414.

14. Gaithersburg MD. Official methods of analysis of AOAC (Association of Official Analytical Chemists) International. 17th ed. AOAC International. 2000;2(6):281-287.

15. Willenborg CJ, Gulden RH, Johnson EN, et al. Germination characteristics of polymer-coated canola (Brassica napus L) seeds subjected to moisture stress at different temperatures. Agronomy Journal. 2004;96(3):786-791.

16. Mizrahi Y. Effect of salinity on tomato fruit ripening. Plant Physiol. 1982;69(4):966-970.

17. Adams P, Ho LC. Uptake and distribution of nutients in relation to tomato fruit quality. Acta Horticulturare. 1995;412(45):374-387.

18. Yildirimi E, Karledag H, Dursun A. Salt tolerance of physalis during germination and seedling growth. Pak J Bot. 2011;43(6):2673-2676.

19. Flowers TJ. Improving crop salt tolerance. Journal of Experimental Botany. 2004;55(396):307-319.

20. Khan MA, Duke NC. Halophytes-A resource for the future. Wetlands Ecol Manage. 2001;9(6):455-456.

21. Lawson SS, Michler CH. Overexpression of AtSTO1 leads to improved salt tolerance in Populus tremula. Transgenic Res. 2014;23:817-826.

22. Helaly AA. Molecular studies on plants to enhance their stress tolerance. $\mathrm{Ph} \mathrm{D}$. dissertation, Germany: University of Potsdam and MaxPlank Institute; 2004. $120 \mathrm{p}$

23. Hipkins MF, Baker NR. Photosynthesis energy transduction. In Hipkins MF, et al. editors. Spectroscopy, IRL, UK: Oxford; 1986. p. 51-105.

24. Cottenie A, Verloo M, Kiekens L Velghe, et al. Chemical analysis of plant and soil. Laboratory of Analytical and Agrochemistry, Ghent, Belgium: State Univ; 1982. p. 100-129.

25. Bates LS, Waldren RP, Teare ID. Rapid determination of free proline for water stress studies. Plant Soil. 1973;39(1):205-207.

26. Smith FMA, Hamilton GDK, Geeds PA. Colorimetric method for determination of sugars and related substance. Anal Chem. 1956;28:550.

27. Snedecor GW, Cochran WG. Statistical Methods 6thed. Press Ames Iowa, USA: Iowa State Univ; 1982. 
28. Levitt J. Responses of plants to environmental stresses . Academic Pres New York USA. 1980;2(1): 607 .

29. Heuvelink E, Bakker M, Sthangellini C. Salinity effects on fruit yield in vegetable crops:a simulation study. Acta Hort. 2003;609:133-140.

30. Morales-Garcia D, Stewart KA, Seguin P. Effects of saline water on growth and physiology of bell pepper seedlings. International Journal of Vegetable Science. 2008;14(2):121-138.

31. Zafar S, Ashraf MY, Ashraf M. Protease activity and associated changes during germination and early seedling stages of cotton grown under saline conditions. International Journal of Biology. 2005;1:103-107.

32. Hussein MM, Oraby SH. Growth and antioxidant enzymes activity in onion plants as affected by thiamine and salinity. Plant Nutrition Management under Water Stress Conditions. 17th International Symposium of CIEC, Cairo, Egypt; 2008. p. 260-278.

33. Chakraborty K, Sairam RK, Bhattacharya RC. Differential expression of salt overly sensitive pathway genes determines salinity stress tolerance in Brassica genotypes. Plant Physiology and Biochemistry. 2012;51:90-101.

34. Ashraf M, Foolad M. Roles of glycine betaine and proline in improving plant abiotic stress resistance. Environmental and Experimental Botany. 2007;59(2):206-216

35. Miranda D, Ulrichs Ch, Fischer G. Imbibtion and percentage of germination of Cape gooseberry (physalis peruviana L) seeds under $\mathrm{NaCl}$ stress. Agronomia Colombiana. 2010;28(1):29-35.

36. Fayza Darwesh MA, Zakher AG. physiological studies on salt tolerance in a new local tomato hybrid. Annals of Agricultural Science, Moshtohor. 2010;48(3):59-71.

37. Mahdi MM, El-Katony MT. Salt tolerance of two wheat genotypes in response of the form of mitroges. Agronomie. 2001;21(3):259-266.

38. Singh SK, Sharma HC, Goswami AM, et al. In vitro growth and leaf composition of grapevine cultivars as affected by sodium chloride. Biol Plant. 2000;43(2):283-286.

39. Spoljarevic M, Agic D, Lisjak M, et al. The relationship of proline content and metabolism on the productivity of maize plants. Plant Signaling and Behavior. 2011;6(2):251-257.

40. Zhang CS, Lu Q, Verma DPS. Removal of feedback inhibition of 1-pyrroline-5-carboxylate synthetase, a bifunctional enzyme catalyzing the first two steps of proline biosynthesis in plants. Journal of Biological Chemistry. 1995;270:20491-20496.

41. Khan NA. NaCl-Inhibited chlorophyll synthesis and associated changes in ethylene evolution and antioxidative enzyme Activities in wheat. Biol Plantarum. 2006;47:437-440.

42. Yasar F, Ellialtioglu S, Yildiz K. Effect of salt stress on antioxidant defense systems, lipid peroxidation, and chlorophyll content in green bean. Russian J Plant Physiol. 2008;55(6):782-786.
43. Sevengor S, Yasar F, Kusvuran S, Ellialtioglu S. The effect of salt stress on growth, chlorophyll content lipid peroxidation and antioxidative enzymes of pumpkin seedling. African Journal of Agricultural Research. 2011;6(21):4920-4924.

44. Chougui S, Yaklef N, Abdel hamid D. Interaction iron- salinity. 1. Relation of photo synthesis $/ \mathrm{K}^{+}$(Roots) with other morphological, physiological and biochemical aspects of tomato (Lycopersicon esculentum Mill.). Arab univ J Agric Sci. 2004;12(2):481-497.

45. Sawas D, Salem F. Infuence of $\mathrm{NaCl}$ concentration in the nutrient solution on mineral composition of eggplants grown in sand culture. Angew Bot. 1996;70:124-127.

46. GreenwayH, Munns R. Mechanisms of salt tolerance in non-halophytes. Annu Rev Plant Physiol. 1980;31:149-190.

47. Soria T, Cuartero J. Tomato fruit yield and water consumption with salinity water irrigation. Acta Horticulturae. 1997;458:215-219.

48. Cuartero J, Fernandez-Muñoz R. Tomato and salinity. Scientia Horticulturae. 1999;78:83-125.

49. Petersen KK, Willumsen J, Kaack K. composition and taste of tomatoes as affected by increased salinity and different salinity sources. J Hort Sci and Biotech. 1998;73(2):205-215.

50. Davies JN. Effect of nitrogen, phosphorus and potassium fertilizers on the non-volatile organic acids of tomato fruit. J Food and Agric. 1964;15:665-673.

51. Ho LC, Zamski E, Schaffer AA. Photoassimilate distribution in plants and crops. Sink Relationships, Marcel Dekker, Inc; 1996. p. 709-728.

52. Maggio A, Pascale S, Angelino G, et al. Physiological response of tomato to saline irrigation in long-term salinized soils. European Journal of Agronomy. 2004;21(2):149-159.

53. Rhoades JD, Kandiah A, Mashali AM. The use of saline waters for crop production. FAO Irrigation and Drainage FAO Rome Italy; 1992. 48 p.

54. De Pascale S, Barbieri G. Effects of soil salinity and top removal on growth and yield of broad bean as a green vegetable. Scientia Hortic. 1997;71:147-160

55. Parra M, Albacete A, Martinez-Andujar C, et al. Increasing plant vigour and tomato fruit yield under salinity by inducing plant adaptation at the earliest seedling stage. Environmental and Experimental Botany. 2007;60:77-85.

56. Ho LC. The mechanism of assimilate partitioning and carbohydrate compartmentation in fruit in relation to the quality and yield of tomato. J Exp Bot. 1996;47:1239-1243.

57. Jain M, Mathur G, Koul S, Sarin NB. Ameliorative effects of proline on salt stress-induced lipid peroxidation in cell lines of groundnut (Arachis hypogaea L.) Plant Cell Rep. 2001;20:463-468. 